\title{
iNT

\section{Communication of Innovation Messages via the Internet: An Example of Turkish Exporting Firms}

\author{
İnternet aracılığıyla inovasyon mesajlarının iletişimi: Türk ihracatçı firmaları \\ örneği
}

Arif Orçun SAKARYA¹, sakarya@cankaya.edu.tr

DOI: 10.34231/iuyd.628567

In a firm, innovation mainly targets to preserve competitive advantage via commercialization. The objective of this study is to examine the extent of website innovation statements of Turkish firms listed in the top one thousand exporter firms' ranking of the Turkish Exporters Assembly. To do this, website contents that are closely related to the notion of innovation are examined. Content analysis methodology is used to group websites which contain innovation related statements. The groups consist of values, vision, mission, research and development activities, and topics related to innovative activities. At the end of the study, it was deduced that businesses are gradually increasing in their innovation awareness as a message to stakeholders, especially in the context of their research and development activities.

Keywords: Inovasyon, araştırma ve geliştirme, paydaş, web sitesi

Jel Codes: $\mathrm{O30}$
Bir firmada inovasyon stratejisi temel olarak rekabet avantajının ticarileşme yoluyla korunmasını amaçlamaktadır. Çalışmanın amacı Türkiye İhracatçılar Meclisinin ilk bin ihracatçı firması listesinde bulunan şirketlerin web sitesindeki inovasyon ifadelerinin kapsaminın incelenmesidir. Bu yönde, web sitelerinin inovasyon kavramıla yakın ilgisi olan içerikleri incelenmiştir. Inovasyon ile ilgili ifadeler içeren web sitelerinin gruplandırlması için içerik analizi yöntemi kullanılmıştır. Gruplar; değerler, vizyon, misyon, araştırma-geliştirme faaliyetleri ve inovatif faaliyetlerle ilgili konulardan oluşmaktadır. Çalışmanın sonunda, firmaların paydaşlarına, temel olarak artan inovasyon farkındalıklarını araştırma-geliştirme faaliyetleri bă̆lamında bir mesaj olarak verdiği sonucuna ulaşılmıştır.

Anahtar Kelimeler: Innovation, research and development, stakeholder, website

Jel Kodlart: $\mathrm{O} 30$

\footnotetext{
${ }^{1}$ Dr. Öğr. Üyesi, Çankaya Üniversitesi, İ̈BF, İşletme Bölümü
} 


\section{Introduction}

With the increasing demand for innovation, firms' related perception is substantial topic. It may be assumed that the means by which firms communicate their innovation-related activities with outside stakeholders, and the meaning of such messages provided by the firms, can be accepted as additional indicators of firm-based innovativeness.

Firms may display their innovation-based activities to their stakeholders via their corporate websites. For this reason, the notion of the "website" is particularly emphasized in this study in order to underline innovation-based messages. Accordingly, this study begins with a literature review that includes three sets of studies. These sets briefly underline the different roles of websites in the framework of firm-stakeholder relation.

Taking into account that the Internet is a popular mean of communication between related parties, the research question becomes: to what degree do firms communicate messages based on innovation, strategies or activities to their stakeholders in order to create value for them in Turkey? Here, it should be noted that according to the literature reviewed, websites are fully available to stakeholders for them obtain the information they need. As the firms in the sample are exporting firms, their websites are also accessible by their foreign stakeholders.

To review the website messages' breadth, content analysis methodology is used to group innovation-related information and remaining notions in the study. The analysis part involves six content groups and 24 innovation attributes of 407 firms for the year 2016. The content group categories first include firm vision, statements in general, values, mission research and development (R\&D) capability, and topics related to innovation. Under these categories; attributes range from design ability to entrepreneurship and creativity, patent activities, $R \& D$ capacity, new product development (NPD) competency, human resources policies, cooperation, quality policy etc. Collection of data is made in such a way to investigate each link in firm websites and their contents which contain expressions on the firm's innovationbased activities or strategies.

\section{Literature Review}

In this section, the first group of studies is related to the communication of corporate identity via websites. Regarding this group of studies, the influence of corporate website on corporate image and reputation is examined by (Ageeva et al, 2018: 287-304) and communication across countries is discussed by (Halliburton \& Ziegfield, 2009: 909-925) in their studies. Moreover, regional cluster firms' identity usage in external communication is searched by (Zamparini \& Lurati, 2012: 498-513). A website based-study of corporate identity building for Indian Banks can be seen in (Fatma \& Rahman, 2014:591-601)'s study and website interactivity's impact on organizational perception is searched by (Guillory\& Sundar, 2014: 44-61). (Bravo et.al, 2012:129-146)'s study examines the relevance corporate social responsibility for Spanish financial entities whereas (Lehoux et al, 2011:61-77) discusses how medical device manufacturers' websites frame the value of health innovation in Canada.

Second group of studies focuses on the usage of websites for different purposes. One of the examples is B2B marketing (Berry \& Gironda, 2019: 138-159), e-commerce (Ghandour, 2015: 
203-222) Internet-based marketing in general (Grubor \& Jakša, 2018: 265-274), relationship marketing (Steinhoff et al, 2018: 369-393), recruiting-related online innovations, (BermúdezEdo et al, 2010: 177-189). As an alternative approach (Zailskaitė-Jakštė \& Kuvykaitė,2010: 849856) mention the use of Internet in higher education institutions and (Vázquez et al, 2015:1-20) application of Internet in tourism mediation, whereas, (Deeter-Schmelz \& Kennedy, 2002: 145154) in industrial communication.

Third group of studies concentrate on the use of websites for value creation, sustainability and communication purposes. In this framework, business communication in general (Boarcăs, 2017: 201-213) communication of values and practices, (Ki \& Shin, 2015: 36-43), usability of the content (Garcia Garcia et al, 2017: 140-154), corporate social responsibility communication (Boateng \& Abdul-Hamid, 2017: 17-31) service for strategic goals (Fisher \& Arnold (2003: 4555), website usage in order to influence perceptions of consumers (Dach \& Allmendinger, 2013: 409-418), determination firms' sustainability efforts on World Wide Web (Gill et al, 2008: 243262), (Dade \& Hassenzahl, 2013: 254-263) are examined. With an different approach of the use of web for sustainability communication in mining industry is searched by (Lodhia, 2014: 142154) and traction of small and medium sized enterprises by (Youtie et al, 2012: 981-995).

\section{Analysis}

\subsection{Sample and Methodology}

The study sample consisted of firms retrieved from a list of the top 1,000 exporting firms according to research conducted by the Turkish Exporters Assembly in 2017 (TIM). Results used in this research were provided at the end of 2016 (TIM, 2018). However, not all firms are included in the study.

There were three major limitations in including all of these firms in the study. First, 259 firms did not mention their corporate names for the research; therefore, these were not included in the study. The second limitation is due to the fact that the websites of 185 firms were inaccessible when the study was conducted in September-November, 2018. Finally, 149 firms did not present any innovation-creativity statement on their websites. Due to these limitations, the study sample includes 407 firms which have accessible websites, with at least a single time emphasis on innovation-creativity on their websites. These firms constituted nearly $55 \%$ of total firms in the TíM study.

Table 1 displays the distribution of industries in the sample. According to this table, the sample is composed of firms from 24 different industries. It should also be noted that potential stakeholder profile differences are omitted from the study for purposes of simplicity. In other words, differences in stakeholder perceptions and characteristics due to different industrial characteristics are not taken into account. 
Table 1. Industrial dispersion of the sample firms

\begin{tabular}{|l|l|}
\hline Jewellery & Ferrous and non-ferrous products \\
\hline Grains and oilseeds & Dried fruits and products \\
\hline Mining & Fresh fruits and vegetables \\
\hline Shipping and yachting & Tobacco \\
\hline Chemical materials and products & Defence and aviation industry \\
\hline Textile and raw materials & Ferrous and non-ferrous products \\
\hline Furniture, paper and forestry products & Seafood and animal products \\
\hline Hazelnuts and products & Steel \\
\hline Olive and olive oil & Ready-made garment and apparel \\
\hline Electric, electronics and services & Machinery and components \\
\hline Automotive industry & Air conditioning \\
\hline Cement, glass and soil products & Carpet \\
\hline
\end{tabular}

As a data analysis method, content analysis was used to reveal attributes of the website-based innovativeness-creativity discourse of the sample. This transformed the contents of the websites visited into a number of innovation-related content categories. To do this, this study followed systematic rules of coding by quantifying and analysing the meanings, presence and relationships of innovation-creativity related concepts and words (Berelson, 1952; Krippendorff, 1980), by examining different information parts of the websites. These parts introduced website users to the firms; in other words, communicating with potential clients, and included data on mission, vision, values, human resources, quality, and research and development policies, actions and statements of the firms. Content analysis counted the word frequency of innovation-creativity related concepts in these areas, which reflected the importance of groups of information, and finally listed topics of the innovativeness-creativity discourse. Then, it combined similar topics together and labelled them as attributes of the innovativeness-creativity discourse.

The data in associated sections of the websites constitute the study's raw data in which content analysis was employed. The following section introduces the findings of the analytical procedures.

\subsection{Findings}

The content analysis derived 24 attributes of innovation-creativity based communication contents from the sample websites. As shown in Table 2, these attributes were classified under 9 categories of the innovation-creativity focused website-based communication discourse. 
Table 2. Categories and attributes of website-based innovativeness discourse

\begin{tabular}{|c|c|}
\hline MISSION & VISION \\
\hline $\begin{array}{l}\text { - Innovation and creativity: Design } \\
\text { and management } \\
\text { - Innovation follow-ups/technology } \\
\text { development } \\
\text { - R\&D activities in general }\end{array}$ & $\begin{array}{l}\text { - } \quad \text { Creativity, Innovation and R\&D } \\
\text { - Entrepreneurship }\end{array}$ \\
\hline VALUES & STATEMENTS IN GENERAL \\
\hline $\begin{array}{ll}\text { - Innovativeness and creativity } \\
\text { - } R \& D\end{array}$ & $\begin{array}{l}\text { - R\&D: Capability and activity } \\
\text { - Innovative } \\
\text { product/creativity/follow-ups }\end{array}$ \\
\hline $\begin{array}{l}\text { HUMAN RESOURCES (HR) POLICIES IN } \\
\text { GENERAL }\end{array}$ & R\&D RELATED TOPICS \\
\hline $\begin{array}{l}\text { - The motivation for creativity, R\&D } \\
\text { ability, entrepreneurial approach(es) }\end{array}$ & $\begin{array}{l}\text { - Design capability/activity(activities) } \\
\text { - New product development activities } \\
\text { - Patent activities (applications) } \\
\text { - Collaboration with academia and } \\
\text { research institutions }\end{array}$ \\
\hline QUALITY POLICY & R\&D POLICY \\
\hline $\begin{array}{l}\text { - Innovation/creativity/technology } \\
\text { innovation } \\
\text { - } \text { and follow up as a quality policy } \\
\text { - } R \& D \text { as a basis for quality policy } \\
\text { implementation }\end{array}$ & $\begin{array}{l}\text { - Innovation as a basis for the } \\
\text { implementation of R\&D policy } \\
\text { - R\&D as a basis for the } \\
\text { implementation of the innovation } \\
\text { policy }\end{array}$ \\
\hline \multicolumn{2}{|l|}{ OTHER } \\
\hline $\begin{array}{l}\text { - } \text { Presence of an R\&D page } \\
\text { - Presence of an "innovation" page } \\
\text { - R\&D team/department and /or lab. } \\
\text { possession } \\
\text { - R\&D Centre possession } \\
\text { - Innovation/Technology Centre } \\
\text { possession }\end{array}$ & \\
\hline
\end{tabular}

According to Figure 1, the most frequently mentioned innovation-creativity related attributes are included under the "general statements" category $(74,9 \%)$ and "R\&D related discourse" category $(69,7 \%)$, followed by the "other" statements category $(61,7 \%)$. Whereas the least frequently mentioned statements appeared under the R\&D policy and quality policy categories of the websites. 


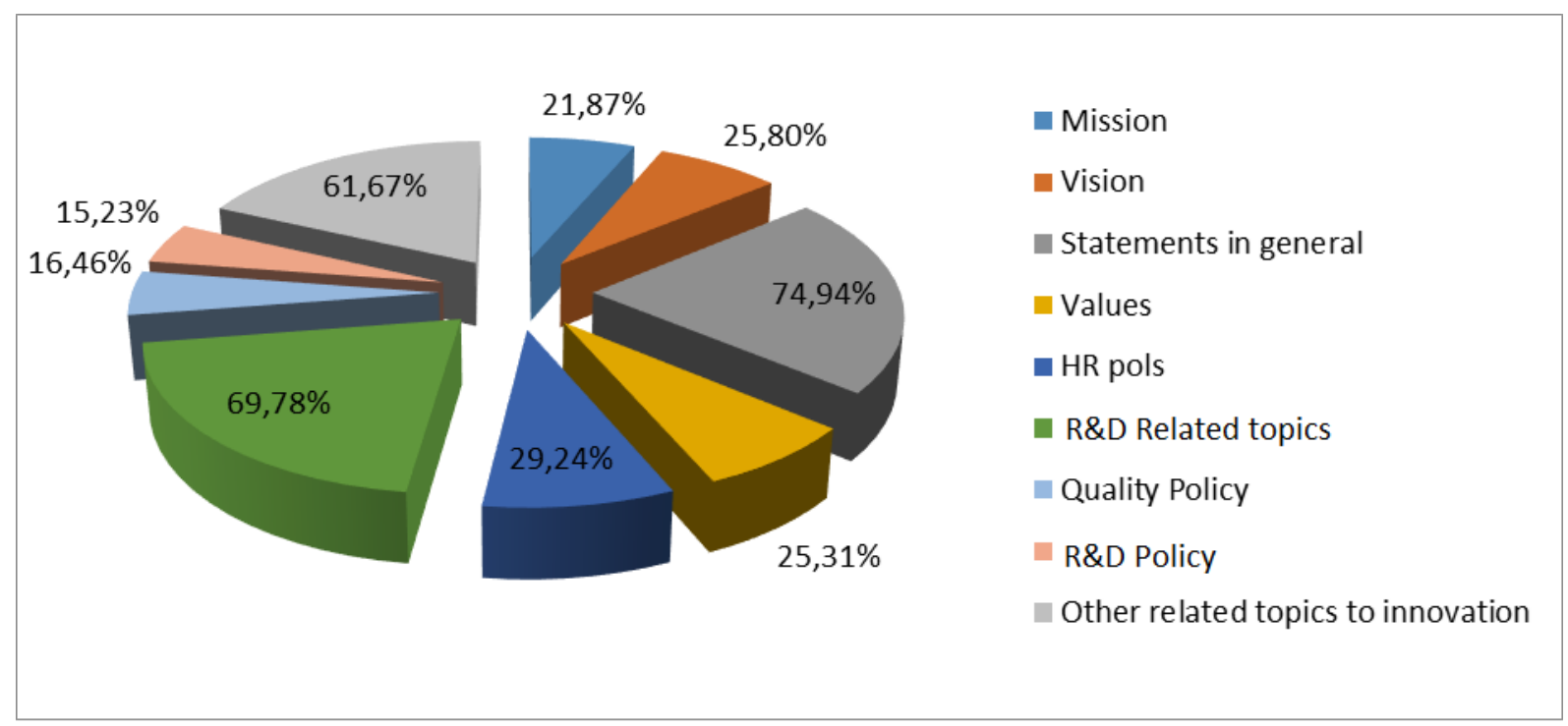

Figure 1. Dispersion of the statements under content group categories

Table 3 demonstrates the concentration of areas of innovation messages provided by the firms on their websites. Of the responding firms with a mission statement, innovation and creativity in a design and management context is the most frequently stated attribute $(76,4 \%)$. A similar situation is valid for vision $(98,1 \%)$ and values $(97 \%)$. Therefore, it can be deduced that the main findings of Table 3 are conclusive for the strategic and cultural contexts.

Design is the most significantly stated attribute when R\&D is discussed, regarding the close relationship between $R \& D$ and design activities (53,5\%), and displays a normal relationship. As one might expect, this is followed by new product development activities (25\%).

Since there is no room to compare the content related to HR policies, it can also be observed that the firms' emphasis on HR-related topics is relatively low when considered with other content categories $(29,24 \%)$

Regarding the R\&D related topics, almost half of the firms mention "design" (53,2\%) as one of the significant attributes within this category. This is followed by "new product development" (25\%) where "patent" and "collaboration" activities are yet to be mentioned as content of communicated messages.

In the context of a quality policy, it can be observed from Table 3 that across the 62 firms in question, "innovation awareness" is highly communicated as an integral part of the quality policy and creativity motivation $(92,5 \%)$, whereas R\&D's concentration on quality is relatively low when compared to awareness. It can be suggested that firms mostly focus on the perception of innovation rather than related processes.

Similar to the quality policy, among messages on R\&D policy, innovation is also seen as a significant part of the communicated R\&D activities.

In the "other" category, it can be deduced that the distribution is almost equal in all firms.

The Presence of R\&D page link tops the process (29,8\%), followed by Presence of an "innovation" page/link (24,3\%) and R\&D centre possession (22,7\%) with 57 firms. 
Table 3. Frequency tables mentioning attributes of 9 categories

\begin{tabular}{|c|c|c|}
\hline MISSION & TOTAL* & PERCENT \\
\hline Innovation and creativity: Design and management & 68 & $76,40 \%$ \\
\hline Innovation follow-ups/technology development & 10 & $11,24 \%$ \\
\hline R\&D activities in general & 11 & $12,36 \%$ \\
\hline TOTAL FIRMS & 89 & $21,87 \%$ \\
\hline \multicolumn{3}{|l|}{ VISION } \\
\hline Creativity, Innovation and R\&D & 103 & $98,10 \%$ \\
\hline Entrepreneurship & 2 & $1,90 \%$ \\
\hline TOTAL FIRMS & 105 & $25,80 \%$ \\
\hline \multicolumn{3}{|l|}{ VALUES } \\
\hline Innovativeness and creativity & 100 & $97,09 \%$ \\
\hline R\&D & 3 & $2,91 \%$ \\
\hline TOTAL FIRMS & 103 & $25,31 \%$ \\
\hline \multicolumn{3}{|l|}{ STATEMENTS IN GENERAL } \\
\hline R\&D: Capability and activity & 101 & $33,11 \%$ \\
\hline Innovative product/creativity/follow-ups & 204 & $66,89 \%$ \\
\hline TOTAL FIRMS & 305 & $74,94 \%$ \\
\hline \multicolumn{3}{|l|}{ HR POLICIES IN GENERAL } \\
\hline $\begin{array}{l}\text { Motivation for creativity, R\&D ability, entrepreneurial } \\
\text { approach(es) }\end{array}$ & 119 & $100 \%$ \\
\hline TOTAL FIRMS & 119 & $29,24 \%$ \\
\hline \multicolumn{3}{|l|}{ R\&D RELATED TOPICS } \\
\hline Design capability/activit(ies) & 152 & $53,52 \%$ \\
\hline New product development activities & 71 & $25,00 \%$ \\
\hline Patent activities (applications) & 26 & $9,15 \%$ \\
\hline Collaboration with academia and research institutions & 35 & $12,32 \%$ \\
\hline TOTAL FIRMS & 284 & $69,78 \%$ \\
\hline \multicolumn{3}{|l|}{ QUALITY POLICY } \\
\hline $\begin{array}{l}\text { Innovation/creativity/technology innovation } \\
\text { and follow up as a quality policy }\end{array}$ & 62 & $92,54 \%$ \\
\hline R\&D as a basis for quality policy implementation & 5 & $7,46 \%$ \\
\hline TOTAL FIRMS & 67 & $16,46 \%$ \\
\hline \multicolumn{3}{|l|}{ R\&D POLICY } \\
\hline Innovation as a basis for the R\&D policy implementation & 49 & $79,03 \%$ \\
\hline R\&D as a basis for the innovation policy implementation & 13 & $20,97 \%$ \\
\hline TOTAL FIRMS & 62 & $15,23 \%$ \\
\hline \multicolumn{3}{|l|}{ OTHER } \\
\hline Presence of a R\&D page/link & 75 & $29,88 \%$ \\
\hline Presence of an "innovation" page/link & 61 & $24,30 \%$ \\
\hline R\&D team/department and /or lab. possession & 30 & $11,95 \%$ \\
\hline R\&D Center possession & 57 & $22,71 \%$ \\
\hline Innovation/Technology Center possession & 28 & $11,16 \%$ \\
\hline TOTAL FIRMS & 251 & $61,67 \%$ \\
\hline
\end{tabular}

* Number of Responding Firms 


\section{Discussion and Conclusion}

This study examines the extent of firms' innovation messages with their present or potential stakeholders. To do this, it examined the websites of 407 firms accessed from the list of the top 1,000 exporting firms for the year 2016. With the help of content analysis, it revealed the dimensions and attributes of innovation-creativity focused communication discourses of these firms. The findings of the study displayed 9 dimensions and 24 attributes of innovationcreativity based communication via websites.

In the study, the website categorizations are expected to underline the following rationale;

i. Innovation strategy: Firms' mission and vision

ii. Organizational culture: Firms' values

iii. Parameters supporting innovation process: R\&D capability related topics and R\&D policy

iv. Penetration of innovation into daily and institutional operations: HR policy and "other" topics. Pages which can be assumed as indicators of innovation awareness are also included in this section.

The first finding is related to the strategic approach to innovation. It can be observed that innovation occupies an important place in a firm's strategy. This finding is also consistent with the firms' general statements. Firms primarily mention innovation in terms of innovative products and/or creativity.

However, it can also be seen that the firms' emphasis on innovation is mainly R\&D focused, underlying the importance of the innovation processes of the firms. Therefore, it is revealed that firms consider innovation mostly in technical and operational terms (except HR policies) and put these at the forefront when communicating with stakeholders. In other words, the most frequently mentioned innovation-creativity based statements in the websites are associated with the role of innovation in organizational functions, including design and new product development activities, relatively more than strategy or culture, and it can be suggested that messages mention the "technical" side of in-house operations. Here, it should also be noted that the findings are discussed across the total number of firms.

Regarding the firms' innovation awareness, the existence of R\&D pages, as well as R\&D centres and teams, can be seen as positive indicators of innovation awareness communicated by the firms. One advantage of the R\&D and innovation centres is investment in qualified human resources which is an important factor in transforming research into products or services. However, the inclusion of creativity into HR policies seem to remain as a challenge ahead of the firms in the future. Besides, as previously mentioned, the internalization of innovation in a firm's culture and value falls into the same category.

Based on findings, it can be inferred that firms generally choose communicating their innovation-based commercialization activities by pointing out R\&D capabilities (mostly "processes"). 
As quantities of R\&D activities act as essential signs of firm innovativeness, related messages of commercialization and value creation are indirectly disseminated with R\&D activity provided creativity gains. This result is also consistent with the government policies which mainly aim improvement of firm-based R\&D activities. The findings are also relevant in a way to reflect the firm priorities and the main highlights that firms communicate with their stakeholders.

One of the biggest limitations of this study was due to the inclusion of different industries. Differences in stakeholder characteristics, market expectations and firm reactions, may end up with differences in firms' attitudes toward innovation (e.g. some of the industries can be more technologically intensive in terms of the raw material procurement). Future in-depth interviews with managers of different types of firms create an area for further research that could explore value creation processes in different industries and related comparisons can be made in this context.

\section{References}

Ageeva, E., Melewar, T.C., Foroudi, P., Dennis, C. \& Jin, Z (2018). Examining the influence of corporate website favorability on corporate image and corporate reputation: Findings from fsQCA. Journal of Business Research, 89, 287-304.

Berelson, B. (1952). Content analysis in communication research. New York: Hoffner Publishing Co.

Bermúdez -Edo, M., Hurtado-Torres, N. \& Aragón-Correa, J.A. (2010). The importance of trusting beliefs linked to the corporate website for diffusion of recruiting-related online innovations. Information Technology Management, 11, 177-189.

Berry, J.M. \& Gironda J.T. (2019). Operationalizing throught leadership for online B2B marketing. Industrial Marketing Management, 81, 138-159.

Boarcăs, C. (2017). Business communication in the Internet age. Economics, Management, and Financial Markets 12(2), 201-213.

Boateng, H. \& Abdul-Hamid.İ.K. (2016). An evaluation of corporate social responsibility communication on the websites of telecommunication companies operating in Ghana. Impression Management Perspectives, 15(1), 17-31.

Bravo, R., Matute, J. \& Pina, J.M. (2012). Corporate social responsibility as a vehicle to reveal the corporate identity: A study focused on the Websites of Spanish financial entities. Journal of Business Ethics, 107, 129-146.

Dach, L. \& Allmendinger, K. (2014). Sustainability in corporate communications and its influence on consumer awareness and perceptions: A study of H\&M and Primark, Procedia Social and Behavioral Sciences, 130, 409-418.

Dade, A. \& Hassenzahl, D.M. (2013). Communicating sustainability A content analysis of website communications in the United States. International Journal of Sustainability, 14(3), 254263. 
Deeter-Schmelz, D.R. \& Kennedy, K.N. (2002). An exploratory study of the Internet as an industrial communication tool Examining buyers' perceptions. Industrial Marketing Management, 31, 145-154.

Fatma, B. \& Rahman, Z. (2014). Building a corporate identity using corporate social responsibility: a website based study of Indian banks. Social Responsibility Journal, 10(4), 591601.

Fisher, C.M. \& Arnold, K. (2003). Is your business website effective?. Journal of Promotion Management, 9, 45-55.

Garcia Garcia, M., Carrillo-Durán, M.V. \& Jimenez, J.L.T. (2017). Online corporate communications: website usability and content. Journal of Communication Management, 21(2), 140-154.

Ghandour, A. (2015). Ecommerce website value for SMEs. International Journal of Electronic Commerce Studies, 6(2), 203-222.

Gill, D.L, Dickinson, J.S. \& Scharl, A. (2008). Communicating sustainability A web content analysis of North American, Asian and European firms. Journal of Communication Management, 12(3), 243-262.

Grubor, A. \& Jakša, O. (2018). Internet marketing as a business necessity, Interdisciplinary Description of Complex Systems 16(2), 265-274.

Guillory, J.E. \& Sundar, S.S. (2014). How does web site interactivity Affect Our Perceptions of an Organization? Journal of Public Relations Research, 26, 44-61

Halliburton, C. \& Ziegfeld, A. (2009). How do major European companies communicate their corporate identity across countries? - An empirical investigation of corporate internet communications, Journal of Marketing Management, 25 (9-10), 909-925.

Ki, E.J., \& Shin, S. (2013). Organization sustainability communication (OSC): Similarities and differences of OSC messages in the United States and South Korea. Computers in Human Behavior, 48, 36-43.

Krippendorff, K. (1980). Content analysis: An introduction to its methodology. Beverly Hills: Sage. Lehoux, P., Hivon, M., Williams-Jones, B., Miller, F.A. \& Urbach, D.R. (2012). How do medical device manufacturers' websites frame the value of health innovation? An empirical ethics analysis of five Canadian innovations. Medical Healthcare and Philosophy, 15, 61-77.

Lodhia, S. (2014). Factors influencing the use of World Wide Web for sustainability communication: an Australian mining perspective. Journal of Cleaner Production, 84, 142-154.

TİM (2018) Türkiye İhracatçılar Meclisi 2016, Türkiye'nin İlk İhracatçı 1000 Firması Araştırması, Download Date 8 May 2018 URL https://tim.org.tr/tr/ihracat-arastirma-raporlari-ilk-1000ihracatci-arastirmasi.html

Steinhoff, L., Arli, D.,Weaven, S. \& Kozlenkova, I. V. (2019). Online relationship marketing. Journal of the Academy of Marketing Science, 47, 369-393

Vázquez, C.R., Campo, L.R., Fernández, V.A.M. \& Fernández, M.M.R. (2015). The effects of the application of the Internet and the information communication technologies in the fields 
of tourism mediation. The International Journal of Management Science and Information Technology, 1-20.

Youtie, J., Hicks, D., Shapira, P. \& Horsley, T. (2012). Pathways from discovery to commercialisation: using web sources to track small and medium-sized enterprise strategies in emerging nanotechnologies. Technology Analysis \& Strategic Management, 24(10), 981-995.

Zailskaitè-Jakštė, L., Kuvykaitė, R. (2010). Internet-based communication with target audiences: Case study of higher education institutions, Economics and Management, 15, 849856.

Zamparini, A. \& Lurati, F. (2012). Communicated identities of regional cluster firms Evidence from the Franciacorta wine cluster. Corporate Communications: An International Journal, 17(4), 498-513. 